\title{
The Development of Concept Map-Based Biology Module on Animalia Invertebrate Subject Matter for $\mathbf{1 1}^{\text {th }}$ Grade Students
}

\author{
Khilma Novia Amalina*, Dian Savitri, Annisa Safitri \\ Biology Education, Faculty of Science and Technology, UIN Sunan Kalijaga Yogyakarta \\ Jl. Marsda Adisucipto No 1 Yogyakarta 55281, Indonesia. Tel. + 62-274-540971, Fax. + 62-274-519739 \\ E-mail: khilmanoviaamalina@gmail.com
}

\begin{abstract}
The purpose of this research is to produce Concept Map-Based Biology Module and to know the quality of this module as a teaching material for $11^{\text {th }}$ Grade Students. This research developed by Analysis, Design, Development, Implementation, and Evaluation (ADDIE) model. Instrument that used is checklist Questionaire. The result of Concept Map-Based Biology Module quality by a media expert, a material expert, five peer reviewer, a biology teacher is very good with presentation $86,56 \%$. The quality of this module is rated by fifteen $11^{\text {th }}$ Grade Students of IT Abu Bakar High School too and the result is very good with presentation 83,18\%. So, Concept MapBased Biology Module on animalia invertebrate subject matter has very good quality overall and fit as a teaching material $11^{\text {th }}$ Grade Students.
\end{abstract}

Keyword: Animalia vertebrate, Biology module, Concept map, Teaching materials

\section{INTRODUCTION}

Animalia Invertebrate is a group of animal which does not have spine (backbone). The amount of this animal group reaches $95 \%$ of all animal species which has been known (Solomon, 2008: G-24). Due to the broadness of study related to invertebrate, students are difficult to comprehend the object. Furthermore, the teacher is also being charged to decide the proper teaching materials, one of the important components is using teaching materials or designing teaching materials so that it would be appropriate for the students.

All this time, the teaching materials that have been used by students cannot support them to comprehend the materials. One of them is textbook. The design of the textbook cannot attract the students to read. Furthermore, its content cannot construct student's knowledge (Yezita, 2012: 55). This kind of problem is usually found at school. One of the teaching materials which can be developed to resolve the problem is module. Module is a kind of book for students to study by themselves or by teacher's guidance (Depdiknas, 2008: 13). According to Sukiman (2012: 132) module is one of the teaching materials which has been arranged systematically which contained learning purposes or competencies, materials and activities to reach the purpose. It also contained evaluation tools to attain the purpose of learning process.

According to Benny \& Refni (2015: 79), the use of concept map can help students in learning process because concept map is such a concept in a square or circle that link to each other. Concept map is a visual or graphics tool which can be used to generate and organize concepts or thought (Benny\& Refni, 2015: $80)$.
Therefore, it can be concluded that the problems are how the development of concept map based Biology module as the teaching materials on the sub-subject of Animalia invertebrate for students, how the quality of the development of concept map based Biology module, and how students response the development of concept map based Biology module as the teaching materials on the sub-subject of animalia invertebrate? In this study, students that become the object of the research is students class X SMA IT Abu Bakar Yogyakarta.

\section{MATERIALS AND METHODS}

The kind of this research is Reseach Development to make a product and to examine the product. The product created from this research is The Concept Map Based Biology Module on the Sub Subject of Animalia Invertebrata for students class X SMA/MA. This research used development model of ADDIE (Analysis, Design, Development, Implementation, and Evaluation) (Tageh, 2014). However, this research would end in development stages. In this research, there will be a limited test to examine the quality of the module.

The phases to arrange the module are: a) Analysis, which include analysis of need, curriculum, instructional, material, students characteristic; b) Design; c) Development; d) Implementation; e) Evaluation (Tageh, 2014). 


\section{RESULTS AND DISCUSSION}

The Development of Concept Map Based Biology Module as a Teaching Material on the Sub-Subject of Animalia Invertebrate

The arrangement of the product is developed based on ADDIE model which include four phases: analysis, design, development, implementation, and evaluation. However, this research would end in development stages.

\section{Analysis}

There are five kinds of analysis which need analysis, curriculum analysis, instructional analysis, material analysis, student characteristic analysis.

\section{Needs Analysis}

This kind of analysis is to discover the importance of module development to fit student's needs.

2. Curriculum Analysis

The module refers to KTSP 2006 (Education Unit Level Curriculum). The standard of competence to be attained by the students is that students are able to apply the principle of living things grouping to study the diversity and the role of biodiversity for life. The basic competence to be attained by students is to describe and communicate the characteristics of animalia kingdom and its role for life. The principal of KTSP 2006 are learning process using multi-strategy education, multimedia, and adequate technology (BSNP, 2006: 11)

3. Instructional Analysis

This is the description phase of Competence Standa- rd which will be learning indicator for students.

4. Material Analysis

Material analysis that is developed for the module is the sub-subject of animalia invertebrate.

5. Student Characteristic Analysis

This analysis is obtained by observation with students and learning process. The result of analysis is: $8 \%$ of the using of teaching material by the teacher are rarely applied, $72 \%$ of teaching materials are less interesting, 39\% of language usage is difficult, and $54 \%$ of teaching materials can not develop student's thinking ability.

\section{Design}

The design is created on Microsoft Word 2013, after that, it will be arranged and redesigned using CorelDraw X8. Then, it will be consulted to the lecturer to get any comment.

\section{Develop}

The module draft that had been revised by the lecturer will be studied by the researcher. The assessment will be done using instrument.

The Quality Assessment of Concept Map Based Biology Module as a Teaching Material on the SubSubject of Animalia Invertebrate

The quality of the developed module will be assessed by a media expert, a material expert, five peer reviewers, and a Biology teacher. The assessment will be followed by several revision until the module is feasible to use. The validation result of the module can be seen in Table 1 .

Table 1. The resume of concept map based module validation.

\begin{tabular}{|c|c|c|c|}
\hline Validator & Aspect of Assesment & Average & Criteria \\
\hline Media Expert & $\begin{array}{l}\text { - Presentation Technique } \\
\text { - Material Presentation } \\
\text { - Graphics }\end{array}$ & $80,51 \%$ & Good \\
\hline Material Expert & $\begin{array}{l}\text { - Material Coverage } \\
\text { - Material Accuracy } \\
\text { - Concept maps } \\
\text { - Linguistic } \\
\text { - Sophistication } \\
\text { - Stimulate curiosity }\end{array}$ & $83,9 \%$ & Very Good \\
\hline Peer reviewer & $\begin{array}{l}\text { - Material Coverage } \\
\text { - Concept maps } \\
\text { - Linguistic } \\
\text { - Sophistication } \\
\text { - Stimulate curiosity } \\
\text { - Presentation technique } \\
\text { - Graphics }\end{array}$ & $91,68 \%$ & Very Good \\
\hline Biology Teacher & $\begin{array}{l}\text { - Material Coverage } \\
\text { - Material Accuracy } \\
\text { - Concept maps } \\
\text { - Linguistic } \\
\text { - Sophistication } \\
\text { - Stimulate curiosity } \\
\text { - Presentation technique } \\
\text { - Presentation materials }\end{array}$ & $85,55 \%$ & Very Good \\
\hline Student Response & $\begin{array}{l}\text { - Material coverage } \\
\text { - Presentation } \\
\text { - Learning independence } \\
\text { - Learning motivation }\end{array}$ & $83,18 \%$ & Very Good \\
\hline
\end{tabular}




\section{Media Expert}

The quality assessment of concept map based Biology module by media expert includes three aspects which are presentation technic, material presentation and graphic (Istiana, 2017: 133-134: Ristanti, 2017: 143; Wiyarsi \& Sutiman, 2009: 84). The assessment of biology module by media expert generally receive good assessment. The material presentation gets the highest assessment with an ideal percentage of $81.81 \%$. This proportion shows that the concept map-based biology module has a good material presentation criteria because it has a module use direction and anatomy module to help the students in learning the module. Furthermore, the table of contents and the list of picture can help the students to search the page in the module or see picture they wanted, concept map can always motivate the student in every activity.

The aspect of presentation technic receives a lower score than the aspect of material presentation with 80 $\%$ ideal percentage. This proportion shows that concept map based biology module has a good material presentation criteria because that material is arranged systematically from the simple to the complex. Furthermore, the explanation of material in every learning activity is proportional to standard competency and basic competency consideration. The composition of the chapters and paragraphs are easy to understand.

The aspect of the graphic also gets a lower score than the aspect of material presentation with $80 \%$ ideal percentage. It shows that the concept map-based Biology module have good criteria on the layouts of the text, the color composition of the text with the right background color, the right image and graphic presentation, the precise image size and focus, the attractive module cover, and the interesting pages.

\section{Material Expert}

The assessment by material expert includes 6 aspects which are material coverage, material accuracy, concept map, linguistic, sophistication, and stimulating curiosity (Istiana, 2017: 131-132; Ristanti, 2017: 143; Wiyarsi \& Sutiman, 2009: 84). The assessment of Biology module by the material expert get a good mark in all aspects. The aspect of material accuracy get the highest rating with $88.88 \%$ ideal percentage. It shows that the concept map-based biology module has good material accuracy criteria, because the material which had been presented is very efficient and understandable, the presentation of the material concept is very clear, the concept of the material is suitable to biological science, the images and the material that had been presented are very appropriate, material in the form of facts were presented is correlated to the reality.

The aspects of concept map, material coverage, and linguistics were assessed with $86 \%, 85.71 \%$, and $84.44 \%$ percentage. This proportion shows that the concept map-based Biology module has a good concept map criteria, material coverage, and linguistic criteria. The aspect of concept map consists of clarity in material, concept map in material, suitability of concept map with the material, the effectiveness of learning evaluation using concept map, the accuracy of concept map as an alternative for student to learn, the accuracy of concept map in locating the misunderstanding.

The aspect of stimulating students' curiosity get $80 \%$ ideal percentage. It shows that the concept mapbased biology module has good criteria. The aspects of stimulating students' curiosity consists of material explanation and biological information which is presented to stimulate students to think further, to do exercise, to do the practicum activities, to discuss, and the evaluation to encourage students to obtain information and various sources.

\section{Peer Reviewer}

The assessment by peer reviewer includes 9 aspects which are material coverage, material accuracy, concept map, linguistic, sophistication, stimulating curiosity, presentation technique, material presentation, and graphics (Istiana, 2017: 131-134; Ristanti, 2017: 143; Wiyarsi \& Sutiman, 2009: 84). The assessment of the biology module by peer reviewers in all aspects are assessed very well. Material accuracy aspects get the highest rating with $98.66 \%$ ideal percentage. It shows that the concept map-based biology module has very good material accuracy criteria. In line with the assessment carried out by material specialist, the accuracy aspect of the material received an ideal percentage of $88.88 \%$ with the quality in the Very Good category.

The aspect of graphics gets the lowest rating with $88.33 \%$ in a Very Good quality (SB). The criteria of graphical aspect includes the layout, the proportion and the composition of the colors, the presentation of images and graphics, the size and focus of images, the cover of display, material appearance, evaluation display, image display, text layout, design consistency, material emphasis signs, the use of bold, italic, and color, and also the accuracy in the selection of fonts.

\section{Biology Teacher}

The assessment by biology teachers consists of 9 aspects which are material coverage, material accuracy, concept map, linguistic, sophistication, stimulating curiosity, presentation techniques, material presentation, and graphics (Istiana, 2017: 131-134; Ristanti, 2017: 143; Wiyarsi \& Sutiman, 2009: 84). The assessment of biology modules by biology teachers in all aspects get a very good assessment. The presentation aspect of the material gets the highest rating with $92.72 \%$ ideal percentage in the Very Good category of quality. It shows that the concept mapbased Biology has a very good aspect of material presented. The assessment carried out by media experts on the aspect of a presentation of the material, the ideal percentage was $81.81 \%$ with the Very Good (SB) quality category.

The aspects of linguistic get the lowest rating with an ideal percentage of $71.11 \%$ with Good quality (B). It shows that the concept map-based biology has good 
linguistic aspects, because the use of language in each learning activity is quite suitable with the EYD, the use of language is quite suitable with the level of student's cognitive development.

\section{Student Response}

The responses of the students od SMA IT Abu Bakar Yogyakarta include 5 aspects which are material coverage, presentation, learning independence, learning motivation, and reading interest (Istiana, 2017: 146147). Student responses to biology modules in all aspects get an ideal percentage of $83.18 \%$ with Very Good quality category (SB). The aspect of material coverage gets the highest rating with $86.85 \%$ ideal percentage in Very Good category (SB). It shows that the concept map-based biology module has good material coverage criteria. The aspect of material coverage consists of 7 criteria, including invertebrate animalia material that can be understood easily, the images presented make the students are easy to understand the material, the table of contents and the list of images makes it easy to search material and images.

The aspect of reading interest gets the lowest rating at $81.2 \%$ in Very Good quality (SB). It is because the students are interested in reading the module. The module makes the students are enthusiastic about reading. The module makes the students aware of the importance of reading. The module also engages the students to use the time to read. The module encourages the students to search another source of reading. It is related to Fathurrohman (2012) that states that reading interest is an active mental tendency to understand language patterns to obtain information that is closely related to willingness, activities and feelings of pleasure that potentially enable individuals to choose, pay attention, and receive something that comes from the outside. Furthermore, the interest has a very large influence in reading, because if the teaching materials (modules) are not studied according to the interests of students, then students will not be able to read well.

\section{CONCLUSIONS}

From the study, it can be concluded that the developed modules produce a concept map based biology module on the sub-subject of animal invertebrate for students of class X SMA / MA. It is developed by analyzing several things including needs, curriculum, instructional, material and student characteristics. The module was consulted with media expert, lecturers and biology teachers. The module is also had several revisions.

The quality of the concept map-based biology module is in the excellent category with an ideal percentage of $86.66 \%$. So that the module can be used as an independent biology teaching material on the subject of animalia invertebrate for students class $X$ of SMA Abu Bakar Yogyakarta.

The response of students class X of SMA IT Abu Bakar Yogyakarta is very good on the concept mapbased biology module. It can be seen by $83.18 \%$ ideal percentage. So that the concept map-based biological module can be used as an independent Biology teaching material on the subject of animalia invertebrate.

\section{REFERENCES}

Beny \& Refni, 2015. Implementasi Strategi Peta Konsep (Concept Mapping) Dalam Program Tutorial Teknik Penulisan Artikel Ilmiah Bagi Guru. Jurnal Pendidikan Terbuka dan jarak Jauh. 16: 79 .

Departeman Pendidikan Nasional. 2003. Standar Kompetensi Mata Pelajaran Biologi. Jakarta : Departemen Pendidikan Nasional.

Fathurrohman, Muhammad. 2012. Belajar dan Pembelajaran: Meningkatkan Mutu Pembelajaran Sesuai Standar Nasional. Yogyakarta: Teras Istianah, Fitri Nur. 2017. Pengembangan Modul Biologi Berbasis Islam-Sains pada Sub-Materi Pokok Sistem Saraf untuk Siswa Kelas XI Madrasah Aliyah. (Skripsi), UIN Sunan Kalijaga Yogyakarta, Yogyakarta

Solomon, Eldra \& Berg Linda R. 2011. Biology. Australia: Cengange Learning.

Sukiman. 2012. Pengembangan Media Pembelajaran. Yogyakarta: Pustaka Insan Madani.

Tegeh, I Made.dkk. 2014. Model Penelitian Pengembang. Yogyakarta: Graha Ilmu.

Yezita, Elva, Media Rosha, \& Yerizon. 2012. Mengkonstruksi Pengetahuan SiswaPada Materi Segitiga Dan SegiempatMenggunakan Bahan Ajar Interaktif Matematika Berbasis Konstruktivisme. Jurnal Pendidikan Matematika. 1:1. 